\title{
PERAN PERGURUAN TINGGI DALAM MENGHADAPI MASYARAKAT EKONOMI ASEAN
}

\author{
Khoirurrijal \\ Program Pascasarjana STAIN Jurai Siwo Metro Lampung \\ khoirurrijal@yahoo.com
}

\begin{abstract}
ASEAN Economic Society forces the workers to compete for employment opportunities in ASEAN countries, especially local workers from South East Asia. The workers who have high job competition absolutely receive more benefit than others. Improving human resources is needed to face this situation, especially for University graduates, to create international graduates who have professional skills, language skills, and cross-cultural skills. To fulfill the international standard, the University must increase their lecturer quality, curriculum, and facilities. Universities are also to develop good cooperation ability with others institution and development student's activity unit which is expected to create educated and skilled human resources. Indonesia will become the big country and capable of being "Man of the Match" or it could even be worse because of the its competition as the of joining MEA.
\end{abstract}

Key words: University, Human Resources, MEA

\begin{abstract}
Abstrak
Dengan adanya Masyarakat Ekonomi ASEAN (MEA), para tenaga kerja harus dapat bersaing merebut peluang kerja di negara-negara ASEAN, khususnya tenaga kerja lokal di negara sendiri maupun yang berasal dari Asia Tenggara. Tentu saja untuk pekerja yang memiliki persaingan kerja yang tinggi yang akan memiliki kesempatan yang lebih luas untuk mendapatkan keuntungan. Maka kualitas Sumber Daya Manusia (SDM) harus ditingkatkan, terutama untuk lulusan Universitas, Perguruan Tinggi, didorong untuk menghasilkan kualitas lulusan internasional dilengkapi dengan keterampilan profesional, keterampilan bahasa dan keterampilan lintas budaya. Tapi pada dasarnya Perguruan Tinggi harus meningkatkan kualitas dosen, kurikulum dan fasilitas untuk memenuhi standar internasional. Selain itu, Perguruan Tinggi juga dituntut untuk mengembangkan keterampilan yang baik dalam kerjasama dengan lembaga atau pihak lain dan pengembangan unit kegiatan mahasiswa yang diharapkan dapat menciptakan SDM yang berpendidikan dan berketerampilan terlatih. Dengan bergabungnya Indonesia sebagai anggota MEA, akan banyak perubahan yang dialami oleh Indonesia. Indonesia bisa menjadi negara besar dan mampu menjadi "Man Of The Match" atau bahkan bisa menjadi lebih buruk karena persaingan itu.
\end{abstract}

Kata Kunci: Perguruan Tinggi, sumber daya manusia, MEA

\section{Pendahuluan}

Masyarakat Ekonomi ASEAN (MEA) yang telah dimulai pada akhir tahun 2015 adalah bentuk integrasi ekonomi ASEAN yang direncanakan akan dicapai pada tahun 2015 dan seharusnya negara-negara ASEAN termasuk Indonesia siap menghadapi ASEAN Free Market ini. Dan pelaksanaan AFTA tinggal beberapa bulan lagi, dengan pelaksanaan AFTA adalah negara-negara ASEAN akan memiliki pasar tunggal yang dinamis dan kompetitif. Kondisi ini dapat menjadi 
tantangan dan ancaman, juga dapat menjadi kesempatan emas pada akhir 2015 dan akan menjadi batas waktu bagi Indonesia untuk memasuki MEA. Masyarakat Ekonomi ASEAN akan membuka batas-batas aturan tentang pajak, tarif dan bea untuk barang dan jasa di Asia Tenggara. Dan kehadiran MEA akan mempengaruhi tidak hanya sektor perdagangan bebas untuk produk-produk yang berbeda tetapi juga akan mempengaruhi sektor tenaga kerja, selain MEA, negara-negara ASEAN akan bebas untuk bersaing dalam mengisi tenaga kerja sektor di semua negara-negara ASEAN.

Kesadaran tentang pentingnya sistem pendidikan nasional Indonesia yang kuat dan kualitas untuk mempertahankan kemajuan bangsa, Indonesia harus segera fokus untuk melawan tantangan dalam mewujudkan dan mempercepat peningkatan kualitas pendidikan agar tidak tertinggal dengan negara-negara lain, dengan mempercepat perbaikan sistem pendidikan dan sumber daya manusia berkemajuan, Oleh karena itu, Indonesia harus segera memberikan perhatian serius terhadap pendidikan, meciptakan di semua tingkatan untuk memiliki harapan yang memiliki kualitas dan dapat diarahkan untuk mendukung kemajuan dan kesejahteraan bangsa dan setiap generasi adalah tantangan dan masalah yang berbeda yang dihadapi sebagaiman Sayyidina Ali bin Abu Tholib mengingatkan kita bahwa: Allimu auladakum ghaira ma ullimtum fainnahum khuliku lizamanin ghaira zamanikum. (Siapkan anak muda/anak Anda dengan hal-hal yang prospektif dan relevan dengan masa depannya nanti).

MEA pada akhir tahun 2015 telah berada di depan mata akan menjadi tantangan dan harapan serta perhatian semua pihak, bukan hanya pemerintah Indonesia. Semua pemangku kepentingan baik tingkat pusat dan daerah penting untuk mempersiapkan langkah-langkah, termasuk perguruan tinggi perlu memperkuat semua aspek pendidikan.

Berdasarkan data dari angkatan kerja Indonesia mencapai 118.170.000 orang. Sementara pengangguran mencapai 7.150 .000 orang. Angkatan kerja Indonesia masih didominasi oleh lulusan SD. Dari 118.170.000 orang yang bekerja, 55.300.000 orang atau 46,80 persen dari lulusan SD. Kemudian pekerja lulusan SMA sebesar 21,1 juta orang atau 17,82 persen. ${ }^{1}$

Untuk negara yang memiliki tenaga kerja dengan kualifikasi pendidikan dan kompetensi yang tinggi, MEA akan menjadi kesempatan untuk memperluas tenaga kerja ke negara-negara ASEAN lainnya. Oleh karena itu, Lembaga Pendidikan Tinggi Indonesia, diharapkan menghasilkan lulusan yang kompetitif di arena internasional, setidaknya untuk kawasan ASEAN. Hal ini diperlukan untuk menghadapi pasar bebas ASEAN pada tahun 2015, potensi potensi orang Indonesia yang datang dari berbagai lulusan Universitas baik negeri maupun

\footnotetext{
${ }^{1}$ The Central Bureau of Statistics, the workforce in February. 2014
}

RI'AYAH, Vol. 01, No. 01 Januari-Juni 2016 
swasta harus menjadi kekuatan besar yang akan menjadi aset dan investasi besar Indonesia dalam menghadapi MEA pada tahun 2015, Pendidikan Tinggi tentunya harus mampu menghasilkan lulusan yang siap untuk sukses di dunia kerja dan mampu membawa perubahan di dunia ini dengan kekuatan penelitian terapan yang dibutuhkan oleh masyarakat dan industri. Pendidikan berkualitas dalam pembangunan suatu bangsa adalah sebuah kebutuhan. Melalui pendidikan berkualitas dapat lahir SDM yang berkualitas dan berdaya saing sebagai salah satu pembangunan bangsa. Tanpa pendidikan yang berkualitas, maka tujuan pembangunan suatu bangsa tidak dapat terwujud dengan baik. Pendidikan yang berkualitas dan pengembangan kualitas seperti dua sisi mata uang yang tidak dapat dipisahkan satu sama lain.

Dalam konteks Indonesia, Undang-Undang dasar yuridis dari 1945, alinea keempat menyatakan bahwa "... Kemudian daripada itu, untuk membentuk suatu pemerintah negara Indonesia yang melindungi segenap bangsa Indonesia dan seluruh tumpah darah Indonesia dan untuk memajukan kesejahteraan umum, mencerdaskan kehidupan bangsa,... ". Mengacu pada pembukaan bagian UUD 1945, jelas bahwa salah satu tujuan pembangunan nasional adalah dalam rangka kehidupan bangsa. Strategi operasional untuk mencapai tujuan ini adalah melalui upaya pengembangan sektor pendidikan. Oleh karena itu, pendidikan adalah pilar strategis yang tidak bisa digantikan oleh sektor apapun dan telah menjadi komitmen nasional karena negara ini didirikan, sehingga masalah pendidikan selalu menarik untuk dikaji dan dikembangkan. Menurut Barizi mengungkapkan bahwa di era globalisasi ini, pendidikan masih dianggap sebagai kekuatan utama dalam komunitas sosial untuk mengikuti perkembangan Ilmu Pengetahuan dan Teknologi (Iptek). ${ }^{2}$ Oleh karena itu, dalam makalah ini penulis akan mengkaji persiapan Perguruan Tinggi dalam menghadapi MEA.

\section{Studi Teoritis dan Metodologi}

Masyarakat Ekonomi ASEAN pada akhir tahun 2015 adalah bentuk integrasi ekonomi ASEAN. Sebagai referensi oleh semua negara anggota dalam melaksanakan komitmen MEA yang telah ditandatangani oleh para pemimpin negara-negara ASEAN pada bulan November 2007 di Singapura, dengan pelaksanaan ASEAN Free Trade Area (AFTA) atau Masyarakat Ekonomi ASEAN (MEA) pada tahun 2015, negara-negara ASEAN akan memiliki pasar tunggal yang dinamis dan kompetitif. Kondisi ini bisa menjadi ancaman, juga dapat menjadi kesempatan emas bagi masyarakat Indonesia. Terlepas dari siap atau tidak, Indonesia akan segera menghadapi era persaingan bebas di akhir tahun

${ }^{2}$ Barizi A, Menjadi Guru Excellence, (Jogjakarta: Ar-Ruzz Media, 2009), hal..129

RI'AYAH, Vol. 01, No. 01 Januari-Juni 2016 
2015. Era di mana arus barang, jasa, dan investasi akan terbuka untuk semua warga negara-negara sekitarnya. Selain itu, MEA menjadi agenda penting yang tidak hanya menuntut perhatian, tapi pada saat yang sama kesadaran dari semua pihak untuk segera mempersiapkan kebebasan kegiatan ekonomi itu. Beberapa sektor pekerjaan industri yang akan berkembang dan memiliki prospek yang baik dalam perdagangan bebas antara negara-negara ASEAN. Kerja lapangan yang akan menyerap tenaga kerja yang meliputi: Sektor informasi dan tekhnologi, eco-tourism (Travel, Perhotelan), kesehatan, industri dan manufaktur, transportasi (darat, laut dan udara), pertanian, seni, pendidikan, pangan dan sektor usaha lainnya.

Metode penelitian ini menggunakan pendekatan kualitatif dengan metode deskriptif analitik kasus variasi. Metode penelitian deskriptif analitik adalah metode penelitian yang menekankan upaya untuk memperoleh informasi tentang status atau gejala pada saat penelitian, memberikan gambaran tentang fenomena, serta lebih lanjut menjelaskan hubungan, serta menarik pentingnya masalah ini. Sukmadinata mengungkapkan bahwa penelitian deskriptif adalah suatu bentuk penelitian yang paling dasar dan dimaksudkan untuk mendeskripsikan atau menggambarkan fenomena yang ada, baik fenomena yang rekayasa alam atau manusia. ${ }^{3}$

Adapun studi kasus adalah metode untuk mengumpulkan dan menganalisis data yang berkaitan dengan kasus sesuatu. Studi kasus adalah studi dari "sistem terpadu". Kesatuan ini dapat menjadi program, kegiatan, peristiwa, atau sekelompok individu yang terikat oleh tempat, waktu atau ikatan tertentu. Studi kasus umumnya menghasilkan gambar longitudinal hasil pengumpulan dan analisis kasus pada suatu periode. Kasus dapat terbatas pada satu orang, satu lembaga, satu peristiwa atau satu kelompok manusia dan bendabenda kelompok lain yang cukup terbatas yang dipandang sebagai satu kesatuan. Pertanyaan tentang memilih sampel yang menggunakan pendekatan ini tidak sama dengan masalah yang dihadapi oleh penelitian kuantitatif. Sebagai implikasinya, studi menggunakan hasil pendekatan studi kasus tidak dapat digeneralisasi. Oleh karena itu, metode yang digunakan adalah metode deskriptif dengan berbagai metode studi kasus, maka dalam penelitian ini tidak menggunakan hipotesis pada awal diverifikasi, hal ini sesuai dengan yang dikatakan oleh Arikunto yang umumnya adalah hipotesis penelitian nondeskriptif. Bahkan jika petualangan yang hipotetis, ia terjebak sebagai bagian dari upaya untuk membangun dan mengembangkan teori berdasarkan data lapangan (grounded theory). ${ }^{4}$ Pendekatan kualitatif interaktif sengaja dipilih

\footnotetext{
${ }^{3}$ Nana Syaodih, Metode Penelitian Pendidikan. (Bandung: Rosdakarya, 2008), hal.72

${ }^{4}$ Ibid, h. 68
}

RI'AYAH, Vol. 01, No. 01 Januari-Juni 2016 
karena penulis menganggap bahwa karakteristik yang cocok dengan masalah yang menjadi fokus penelitian.

1. Sampel Purposive; Pemilihan sampel purposive atau teoritis peneliti disebabkan ingin meningkatkan cakupan dan jangkauan dari data yang dibutuhkan untuk mendapatkan berbagai realitas.

2. Analiais Data induktif, metode induktif dipilih daripada metode deduktif karena metode ini memungkinkan peneliti untuk mengidentifikasi kenyataannya adalah bahwa berbagai bidang, membuat interaksi peneliti dan responden lebih eksplisit, terlihat, dan mudah dilakukan, serta memungkinkan identifikasi aspek yang saling mempengaruhi.

3. Desain penelitian muncul secara alami; Para peneliti memilih desain penelitian muncul, menempel, mengalir secara bertahap dan tidak dibangun pada awal penelitian. Desain yang timbul sebagai akibat dari fungsi interaksi antara peneliti dan responden.

4. Hasil didasarkan pada negosiasi; Para peneliti naturalistik ingin bernegosiasi dengan responden untuk memahami makna dan interpretasi ihwal data mereka yang diperoleh dari mereka.

5. Batasi fokus penelitian ditentukan; Ranah teritorial penelitian kualitatif sangat ditentukan oleh fokus penelitian yang muncul ke permukaan sehingga fokusnya memungkinkan interaksi yang lebih stabil antara peneliti dan responden dalam konteks tertentu.

6. Latar belakang Alam; ontologis objek untuk dilihat dalam konteks alam, dan pemisahan elemen-anasirnya akan mengurangi tingkat integritas dan kesatuan makna objek.

7. Manusia sebagai instrumen; Peneliti menggunakan dirinya sebagai pengumpul data primer. Benda-benda lain sebagai manusia tidak bisa menjadi alat seperti itu tidak akan dapat memahami dan meyesuaikan diri dengan realitas sejati.

8. Metode kualitatif, peneliti kualitatif memilih metode kualitatif karena metode ini lebih mudah disesuaikan dengan realitas yang beragam dan berinteraksi.

9. Pemanfaatan Peneliti pengetahuan non-proporsional naturalistik melegitimasi penggunaan intuisi, perasaan, firasat dan pengetahuan lainnya yang tidak mendapatkan solusi selain pengetahuan tentang proporsional karena jenis pertama pengetahuan yang banyak digunakan dalam proses interaksi antara peneliti dan responden.

10. Teori berdasarkan data di lapangan; Para peneliti melihat naturalistik untuk teori-teori yang muncul dari data. Mereka tidak berangkat dari teori apriori karena teori ini tidak akan dapat menjelaskan temuan (realitas dan nilai) yang akan dihadapi di lapangan.

RI'AYAH, Vol. 01, No. 01 Januari-Juni 2016 
11. Bagaimana pelaporan kasus; Pelaporan gaya lebih cocok daripada pelaporan ilmiah biasa pada penelitian kuantitatif, karena kasus yang dilaporkan lebih mudah disesuaikan dengan deskripsi realitas di ranah para peneliti.

12. Interpretasi idiograflk; Data yang dikumpulkan meliputi kesimpulan akan interpretasi dalam idiograflk, yaitu dalam kasus, khusus, dan kontekstual. tidak nomotetis, yang didasarkan pada hukum generalisasi.

13. Aplikasi tentatif; Peneliti kualitatif kurang tertarik (diragukan) untuk membuat klaim penerapan temuan karena kenyataannya ia hadapi bermacam-macam.

14. Situasi dengan kriteria tertentu; Istilah-istilah seperti validitas internal, validitas eksternal, keandalan dan objektivitas suara sebagai alien penelitian naturalistik, yang bertentangan dengan aksioma naturalistik. Istilah keempat dalam studi naturalistik diganti dengan kredibilitas, kemampuan untuk mentransfer, ketergantungan. ${ }^{5}$

\section{Diskusi}

Diharapkan kualitas lulusan di sekolah atau Perguruan Tinggi dapat menghasilkan Sumber Daya Manusia (SDM) yang dapat bersaing di era globaliasasi ini sehingga memiliki nilai jual yang siap untuk bekerja agar tidak menjadi "budak" di negeri sendiri.

Penegakan Masyarakat Ekonomi ASEAN (MEA), rakyat Indonesia harus optimis dan itu harus menjadi momentum dan kesempatan emas untuk menghasilkan dan mempromosikan berbagai sektor pembangunan infrastruktur, meningkatkan ekonomi, keamanan, pendidikan dan sosial-budaya. Dalam menghadapi era MEA pada akhir 2015, Indonesia harus mampu bersaing dengan negara-negara lain dengan harapan untuk dapat memanfaatkan peluang, terutama dengan menyiapkan lulusan yang siap mengisi pasar kerja di kawasan ASEAN. Jadi Universitas perlu merevitalisasi diri dan harus mampu berdiri di garis depan dan harus terus memacu diri untuk pengembangan pendidikan di negara yang diharapkan memiliki pendidikan berkualitas tinggi dan daya saing dalam menghadapi pasar ASEAN.

1. Tantangan Pendidikan Tinggi Dalam Menghadapi MEA Pada Akhir Tahun 2015

a. Tantangan utama bagi Indonesia adalah terbatasnya akses ke pendidikan tinggi.

b. Sumber daya manusia (SDM) tidak memenuhi syarat.

c. Tuntutan tinggi dari sumber daya manusia yang kompetitif.

${ }^{5}$ Ibid, hal. 73

RI'AYAH, Vol. 01, No. 01 Januari-Juni 2016 
d. Kemudahan untuk bekerja dengan negara sesama ASEAN dan kemudahan dalam memperoleh visa kerja.

e. Kurangnya penguasaan bahasa Inggris sebagai bahasa komunikasi.

\section{Peran Pemerintah dan Perguruan Tinggi}

Peran pemerintah Indonesia melalui Perguruan Tinggi harus mempersiapkan segala sesuatu dalam menghadapi pasar bebas ASEAN 2015 atau ASEAN Economic Community (AEC) pada tahun 2015, antara lain:

a. Pemerintah dan Perguruan Tinggi diharapkan mampu menciptakan produk baru dan mempertahankan produk Indonesia yang sudah ada yang dikemas dengan cara yang berbeda. Hal ini menjadi penting dilakukan agar batik, tas etnik Aceh, atau kekhususan lainnya yang dimiliki Indonesia dapat dipertahankan.

b. Pemerintah diharapkan mampu mempersiapkan bisnis global yang tangguh, baik kuantitas maupun kualitas dengan mengubah struktur pendidikan ke arah yang lebih profesional, infrastruktur dasar seperti halnya infrastruktur strategis dan membangun perilaku pasar berkearifan lokal.

c. Pemerintah memberikan kesempatan bagi Perguruan Tinggi dalam proses pendidikan atau kursus yang sangat berorientasi pada dunia kerja.

d. Peningkatan kualitas harus ditingkatkan di berbagai lini, baik layanan dan produksi dengan mendirikan produk dan sumber daya manusia (SDM) yang sangat kompetitif dengan kompetensi bersertifikat dan profesional.

e. Indonesia seharusnya tidak hanya fokus pada kekayaan alamnya. Karena dalam pasar bebas, inovasi dan produktivitas yang lebih menuntut untuk dikembangkan, bukan hanya membanggakan sumber daya alam tetapi tidak memproses dengan bijak kebutuhan manajer yang profesional dan pemerintahan yang baik dan benar.

f. Menambah dan memanfaatkan laboratorium secara maksimal, seiring dengan perkembangan pengujian teknologi, laboratorium juga diperlukan untuk memberikan pengujian jaminan kualitas kepada pelanggan, di samping metode yang akan divalidasi, terakreditasi ISO 17025: 2005, dengan menggunakan teknologi terbaru dan laboratorium juga diperlukan untuk berpartisipasi dalam uji profisiensi secara teratur di laboratorium agar kompetensi dan kualitas kebutuhan dapat dipertahankan melalui peran pemerintah dan universitas. Jadi keselarasan dalam langkah untuk memberikan sistem jaminan kualitas, antara pemain laboratorium dan industri harus saling mendukung. Uji laboratorium harus mampu RI'AYAH, Vol. 01, No. 01 Januari-Juni 2016 
memberikan suatu kebenaran dan dapat diterima oleh pelaku pasar dan industri internasional dapat mengontrol kualitas produk mereka dengan melihat hasil nilai yang diuji.

g. Pemerintah bekerja sama dalam upaya meningkatkan pengetahuan, keterampilan dan teknologi sehingga dapat melahirkan tenaga kerja yang handal dalam menghadapi perdagangan bebas, disertai dengan bakat mental yang pada kewirausahaan tahap awal. Dimana persaingan akan semakin ketat dan tinggi. Perusahaan akan mencari karyawan atau tenaga kerja yang memiliki kemampuan untuk menyelesaikan pekerjaan, selain latar belakang pendidikan yang sesuai. ${ }^{6}$

h. Perguruan Tinggi diharapkan mampu bekerja sama dengan Pemerintah dalam meningkatkan layanan sistem yang akan memberikan informasi tentang perdagangan bebas di Asia Tenggara secara teratur dan juga menyediakan sistem online dan terintegrasi yang dapat memfasilitasi segala hal yang berkaitan dengan bisnis, pekerjaan dan lain-lain.

i. Pemerintah Indonesia bekerjasama dengan Universitas meningkatan SDM melalui program beasiswa, baik dalam dan luar negeri untuk memiliki pencapaian target peningkatan jumlah master dan doktor nasional atau internasional.

\section{Solusi Perguruan Tinggi Dalam Menghadapi Mea Pada Akhir Tahun 2015}

a. Masalah utama bagi Indonesia adalah rendahnya tingkat pendidikan pekerja Indonesia karena terbatasnya akses pendidikan tinggi dan tingginya biaya pendidikan di Indonesia, maka solusinya untuk menjamin pendidikan itu adalah dengan adanya Jaminan Pendidikan Nasional (Jamdiknas), yang menuntut pemerintah Indonesia untuk memberikan pelaksanaan pendidikan gratis dan jaminan kualitas sarjana (S1) untuk seluruh anak Indonesia.7 Dengan asumsi bahwa jika anggaran pendidikan nasional mencapai Rp 371.000.000.000.000 ditambah subsidi bahan bakar atas anggaran dan alokasi anggaran, maka dianggap cukup untuk Jamdiknas. ${ }^{8}$

b. Dengan kemudahan bekerja dengan negara sesama ASEAN. Hal ini merupakan tantangan khusus bagi Perguruan Tinggi Indonesia karena akan ada persaingan tenaga kerja, maka perguruan tinggi harus

\footnotetext{
${ }^{6}$ http://www.enterpriseone.gov.sg. Diakses 21 November 2015.

${ }^{7}$ Republika, 28 April 2014

${ }^{8}$ Antara News, 30 April 2014.
}

RI'AYAH, Vol. 01, No. 01 Januari-Juni 2016 
menyiapkan sumber daya manusia atau alumni yang memiliki kompetensi ilmiah, profesional dan memiliki keterampilan yang handal sesuai kebutuhan.

c. Bahasa, lulusan pendidikan tinggi belum mampu secara optimal dalam akuisisi bahasa Internasional, yaitu bahasa Inggris sebagai alat komunikasi dalam menghadapi pasar bebas ASEAN, meskipun diajarkan mulai dari pendidikan dasar sampai perguruan tinggi dan bahkan ada kursus, tapi minat dan kemampuan generasi masih kurang untuk mencoba menguasai bahasa Inggris. Pendidikan Tinggi menuntut agar mahasiswa dan alumni memiliki kemampuan bahasa yang memadai untuk memberikan layanan dalam bentuk infrastruktur, aturan, bahan ajar yang memadai, terutama dalam meningkatkan kemampuan berbahasa Inggris sebagai bahasa internasional. ${ }^{9}$ Pendidikan tinggi harus menyiapkan sumber daya manusia (SDM) yang memenuhi syarat sebagai pekerja dengan kualifikasi pendidikan dan kompetensi yang tinggi. Dengan berlakunya MEA ini akan menjadi kesempatan untuk memperluas tenaga kerja ke negara-negara ASEAN lainnya, peran Sumber Daya manusia (SDM) sangat penting dalam menghasilkan produk yang berkualitas. Para ahli dan tenaga terampil akan mendapatkan akses gratis untuk mencari dan memasuki dunia kerja di wilayah negara-negara ASEAN. Oleh karena itu, ia harus merupakan upaya sistematis yang dilakukan oleh pendidikan tinggi untuk meningkatkan kualitas sumber daya manusia dalam bentuk hard skill dan soft skill. Peningkatan sumber daya manusia yang handal dan kompeten merupakan tanggung jawab bersama antara pemerintah dan masyarakatnya, termasuklah orang tua harus memperhatikan perkembangan pendidikan anak-anak mereka sebagai generasi penerus.

d. Pendidikan tinggi harus menyadari bahwa tuntutan SDM yang kompetitif, langkah yang diambil tidak hanya bersosialisasi, tetapi lebih diharapkan untuk memetakan masalah yang menyebabkan rendahnya daya saing dan mengatasi tindakan antisipatif sehingga sumber daya manusia perguruan tinggi benar-benar dapat memenuhi kebutuhan negara-negara ASEAN.

e. Menurut Adhe Wibisono ${ }^{10}$ bahwa hal dasar yang harus diprioritaskan oleh pemerintah Indonesia ke depan dalam menyambut MEA pada tahun 2015 adalah mengubah orientasi pendidikan dan pengembangan

${ }^{9}$ http://www.menatapaceh.com, Wibowo and Beautiful Names, North Aceh Democratic Community (KDAU), 2014

${ }^{10}$ ASEAN researcher at The Habibie Center, 2014.

RI'AYAH, Vol. 01, No. 01 Januari-Juni 2016 
SDM. Beberapa langkah yang dianggap perlu untuk Indonesia adalah Pemerintah dalam 5 tahun ke depan harus memberikan perhatian untuk meningkatkan kualifikasi pendidikan tenaga kerjanya yang sebagian besar terdiri dari lulusan SD yang setidaknya bisa lulusan SMA. Hal ini dilakukan dalam rangka untuk mendesak para pekerja Indonesia dapat menahan masa depan pasar bebas ASEAN dan pemerintah diharapkan untuk memberantas gejala korupsi sistemik yang terjadi khususnya di sektor pendidikan. Anggaran pendidikan sebesar Rp 371 triliun jika tidak tergerus oleh bancakan korup akan menjadi modal utama pemerintah dalam melakukan program-program pendidikan dan Indonesia diharapkan secara bertahap mereformasi kebijakan pendidikan yang kemudian dapat mendukung pelaksanaan gagasan pendidikan gratis hingga tingkat perguruan tinggi. Pasca penataan anggaran secara efektif dan efisien seperti yang dilakukan Finlandia diharapkan dapat mewujudkan ide. Sementara A. Malik Fajar mengatakan bahwa dalam meningkatkan kualitas pendidikan di perguruan tinggi harus dimulai dengan membangun kepercayaan/ gambar / image baik dosen dan karyawan untuk masyarakat, lembagalembaga pemerintahan yang disiplin, tranfaran dan akuntabel dan pemimpin profesional.

f. Selain di atas, menurut penulis tidak kalah pentingnya adalah diharapkan Pemerintah melalui Perguruan Tinggi untuk menciptakan SDM yang memiliki karakter jujur, bertanggung jawab, bukan mentalitas korupsi, siap barsaing baik nasional maupun internasional. karena keberhasilan pengembangan Indonesia akan menjadi titik awal dari karakter pribadi yang bersih, jujur, dan bertanggung jawab.

\section{Kesimpulan}

Dari paparan di atas, dapat disimpulkan hal-hal sebagai berikut:

1. Tantangan Pendidikan Tinggi dalam menghadapi MEA pada akhir tahun 2015 adalah terbatasnya akses ke pendidikan tinggi, Sumber Daya Manusia (SDM) yang tidak memenuhi syarat, tuntutan tinggi dari sumber daya manusia yang kompetitif, kemudahan untuk bekerja dengan negara sesama ASEAN dan kemudahan dalam memperoleh visa kerja dan kurangnya penguasaan bahasa Inggris sebagai bahasa komunikasi.

2. Pemerintah dan Perguruan Tinggi memiliki peran paling strategis dalam menentukan perkembangan dan kemajuan bangsa dengan segera mengaktifkan sinergi dalam satu kesatuan, visi, misi dan tujuan bersama dalam menghadapi persaingan pasar bebas. Pemerintah harus membantu dana, infrastruktur dan memberikan beasiswa kepada Perguruan Tinggi

RI'AYAH, Vol. 01, No. 01 Januari-Juni 2016 
untuk mendukung kuantitas dan kualitas pendidikan, memfasilitasi kemitraan antara lembaga pendidikan di negeri dan luar negeri untuk mendukung kemajuan sistem pendidikan di Indonesia.

3. Dalam menghadapi MEA pada akhir 2015, Pemerintah harus memberi Jaminan Pendidikan Nasional (Jamdiknas), menyiapkan SDM yang profesional, menguasai bahasa internasional, memiliki karakter jujur, bertanggung jawab bukan mentalitas korupsi, siap barsaing baik nasional maupun internasional.

\section{Daftar Pustaka}

A Barizi, Menjadi Guru Excellence, Jogjakarta: Ar-Ruzz Media, 2009.

Antara News, 30 April 2014

Nana Syaodih, Metode Penelitian Pendidikan, Bandung: Rosdakarya, 2008.

Republika, 28 April 2014

http:/ / www.enterpriseone.gov.sg

http://www.menatapaceh.com, Wibowo and Beautiful, North AcehDemocratic Community (KDAU), 2014

The Central Bureau of Statistics, the workforce in February. 2014

RI'AYAH, Vol. 01, No. 01 Januari-Juni 2016 